\title{
Fundamental concepts: The solution to contemporary management problems - A sine qua non or non sequitur?
}

\author{
K.K. Naidoo* \\ School of Pharmacy \& Pharmacology, University of KwaZulu-Natal \\ Private Bag, X54001, Durban, 4000, South Africa \\ naidookk@ukzn.ac.za
}

Received March 2004

\begin{abstract}
The last quarter of the $20^{\text {th }}$ century, particularly the last decade - with the advent of more sophisticated technology, rising educational levels amongst workers and globalisation - saw the arrival of a plethora of management tools and theories; and notwithstanding the sometimes their contradictory nature; an even stronger and louder message being spread viz. that management in the $21^{\text {st }}$ century would have a different face from that worn in the $20^{\text {th }}$ century. This paper raises various questions: Is contemporary management theory nothing more than an accumulation of contradictory fads? Can universal management principles be extracted from the accumulated mass of information? Do the classical writers have words of wisdom to impart to the manager of the $21^{\text {st }}$ century? In so doing, this paper traces a trajectory of management thought by examining the place of the seminal work of Chester I Barnard of the classical school of thought, in the light of contemporary trends and problems; and debates the currency of fundamental management principles.
\end{abstract}

*To whom all correspondence should be addressed.

\section{Introduction}

Out of the need to separate management duties from that of ownership at the turn of the $20^{\text {th }}$ century, arose the challenge of understanding the functions of managers. This early generation of managers were mainly self-employed family groups, and skilled artisans, who were both employers and owners. They performed all the functions involved in running their businesses.

The Industrial Revolution, brought people together to work in factories and the skilled artisans gave up the autonomy of working in their homes and workshops in order to work on relatively unskilled jobs in factory settings. This gave rise to a need for the efficient planning, organising, influencing and controlling of the work activities (Morgan, 1986; Zuboff, 1988).

The last quarter of the $20^{\text {th }}$ century, particularly the last decade - with the advent of more sophisticated technology, rising educational levels amongst workers and globalisation - saw the arrival of a plethora of management tools and theories and an even stronger and louder message being spread viz. that management in the $21^{\text {st }}$ century would have a different face from that worn in the $20^{\text {th }}$ century (Pascale, 1990; Zuboff, 1988).

This paper traces a trajectory of management thought by examining the place of the seminal work of Chester I Barnard of the classical management school, in the light of contemporary trends and problems and debates the currency of fundamental management principles.

\section{The dilemma of the practising manager}

The confusion of the practising manager is clearly seen in the following excerpt from the book, Managing on the edge: How the smartest companies use conflict to stay ahead (Pascale, 1990:18):

In the past 18 months we have heard that profit is more important than revenue, quality is more important than profit, that people are more important than profit, that customers are more important than our people, that big customers are more important than our small customers, and that growth is the key to our success. No wonder our performance is inconsistent.

In the period from the end of the Second World War to 1990, Pascale estimated that over two dozen management techniques were developed; with at least half of them originating between 1985 and 1990. This increase in the number of new management tools, reasoned Pascale, was due to the popularisation of professional management as a discipline with generic solutions to management problems anywhere. This provided the impetus for the use of mass marketing techniques to disseminate these so-called new techniques, notwithstanding anything contradictory in their content and nature. As a result, this array of management tools became widely available to practising managers, whose use of these tools was aimed at enhancing their competence and job performance. Faced with a deluge of 'management techniques', the practising manager is clearly confronted with a situation of 'tool overload'. And, hence, the dilemma of the practising manager! 
According to Micklethwait and Wooldridge (1996), the speed to development of these new management theories increased two-fold since 1990. A perusal of the current management bookshelves, and the ideologies espoused by many modern management gurus and consultants, shows a vast array of management techniques. Fink (2003) refers to the employment of extremely effective rhetoric to instigate discourse, which propagates 'new ways of thinking' and 'new management principles and philosophies'.

Abrahamson (1996) called 'transitory collective beliefs that certain management techniques are at the forefront of management progress' management fashions. He introduced a systematic framework to analyse fashions in management thinking. He also urged management scholars to study the origin and development of fashions in order to understand how they might influence the management fashion process and ultimately make it more useful for managers and other stakeholders. Other researchers followed Abrahamson's systematic analysis (Kieser, 1997; Benders \& Van Veen, 2001). They illustrated empirically a trend whereby new concepts become popular temporarily and then vanish afterwards.

Rigby (2003) describes a global survey conducted by Bain (2003) , on management tool use and satisfaction, where information was gathered in 2002 from 708 companies on five continents (North and South America, Europe, Asia and Africa); and which found that managers were using more tools than ever to make headway in tough times. Of the 25 different tools used (Table 1), it was found that on average, the companies that were surveyed used 16 such tools in 2002, with the heaviest reliance being on 'compass-setting tools' such as mission and vision statements and strategic planning. The tool that provided the greatest satisfaction score was the enactment of a corporate code of ethics. At the same time, executives discarded tools such as stock buybacks, corporate venturing and merger integration teams.

Viewed from this perspective, very little seems to have changed since Pascale's analysis in 1990.

Is Pascale correct? Is contemporary management theory nothing more than an accumulation of contradictory fashions or fads? Can universal management principles be extracted from the accumulated mass of information? Do the classical writers have any words of wisdom to impart to the manager of the $21^{\text {st }}$ century?

\section{Classical management thought}

While, a comprehensive review and summary of classical theory is far beyond the scope of this paper, the seminal work of a renowned figure in management history - Chester Irving Barnard - has been selected to illustrate the relevance of early contributions to today's professional executive. Barnard's place in the classical management school will be highlighted against the foil of Taylor's Scientific Management Principles.
Table 1: Management tools used in 2002 (Rigby, 2003)

\begin{tabular}{l|c}
\hline \multicolumn{1}{c|}{ Management Tool } & $\begin{array}{c}\text { Percentage Used by } \\
\text { Companies }\end{array}$ \\
\hline Strategic Planning & 89 \\
\hline Benchmarking & 84 \\
\hline Mission and Vision Statements & 84 \\
\hline Customer Segmentation & 79 \\
\hline Outsourcing & 78 \\
\hline Customer Surveys & 78 \\
\hline Customer Relationship & 78 \\
Management & 78 \\
\hline Corporate Code of Ethics & 76 \\
\hline Growth Strategies & 76 \\
\hline Pay-for-Performance & 75 \\
\hline Core Competencies & 70 \\
\hline Contingency Planning & 69 \\
\hline Strategic Alliances & 64 \\
\hline Change Management Programs & 62 \\
\hline Knowledge Management & 62 \\
\hline Balanced Scorecard & 59 \\
\hline Downsizing & 57 \\
\hline Total Quality Management & 54 \\
\hline Reengineering & 52 \\
\hline Supply Chain Integration & 52 \\
\hline Economic Value Added & 50 \\
\hline Analysis & 37 \\
\hline Activity Based Management & 32 \\
\hline Merger Integration Teams & 18 \\
\hline Corporate Venturing & \\
\hline Stock Buybacks & \\
\hline
\end{tabular}

\section{Scientific management}

In his ground-breaking, Principles of scientific management (1911), Frederick Winslow Taylor, the father of scientific management, pioneered five simple principles of management, summarised as follows (Taylor, in Morgan, 1986:30):

1. Shift all responsibility for the organisation of work from the worker to the manager; managers should do all the thinking relating to the planning and design of work, leaving the workers with the task of implementation.

2. Use scientific methods to determine the most efficient ways of doing work; design the worker's task accordingly, specifying the precise way in which the work is to be done.

3. Select the best person to perform the job thus designed.

4. Train the worker to do the work efficiently.

5. Monitor the work performance to ensure that appropriate work procedures are followed and that appropriate results are achieved.

Taylor, in his treatise, acknowledged that workers bring skills to, and learn skills on, the job which allow them to make independent decisions about the best way to accomplish work. He noted (Taylor, 1947:22): 
Foremen and superintendents know, better than anyone else, that their own knowledge and personal skill fall short of the combined knowledge and dexterity of all the workmen under them. The most experienced managers therefore frankly place before their workmen the problem of doing the work in the best and most economical way.

Although glimmers of the contemporary approaches of empowerment and participation shine through in the above paragraph, Taylor recognized the inherent potential for conflict that such independent worker ideology presented to a management intent on controlling and creating predictable organizational outcomes. Therefore, in tandem with the social, economic and political mores of the times, his scientific management theories ignored any ideas of participation and empowerment. It favoured instead the removal of any autonomous decision-making powers from workers, and placed them in the hands of their managers, of whom few knew what was required to improve work processes.

This transference of power of control and its dehumanising effect led to Taylor being known as the 'major enemy of the working man' (Morgan, 1986).

\section{The link between scientific management and human relations}

While the choice of any figure as a reference point for an examination is highly subjective and may even be considered arbitrary, Chester Barnard was selected because his pioneering work represents an important transitional theme, one that bridges the scientific management and human relations viewpoints.

In addition, Barnard was chosen because of the depth and breadth of his personal experience as a management practitioner. Barnard was not an academic but his brief sojourn into academia culminated in his 1938 seminal treatise, The functions of the executive, which will serve as a basis for relating his ideas to the challenges facing today's managers.

\section{Theoretical models}

The rational-model of organisational theory is based on a closed-system strategy. In a closed-system strategy the system is required to be closed or if closure is not complete, that the outside forces acting on it will be predictable. Application of scientific management principles achieves conceptual closure of the organisation by assuming that goals are known, tasks are repetitive, output of the production processes somehow disappears, and the resources in uniform qualities are available. The 'rational school' considers that the organization is a structure designed to achieve goals (Thompson, 1967).

Barnard (1938) made a contribution to the 'rationalist school' of organization theory. His concept of the organization was that it was a deliberately constructed tool a set of rationally designed and monitored tasks. ....an organisation is defined as a system of consciously coordinated personal activities or forces... (Barnard, 1938:72).

However, Barnard also had a symbolic concept of the organisation - as a set of important values, beliefs and moral codes that motivated and guided people to co-operate in the pursuit of the organization's well-being. These values, beliefs and moral codes represent variables not subject to complete control by the organisation and hence not contained within a closed system of logic. With this concept, Barnard also made contributions to the 'naturalist school'. This school has an open-system strategy and considers that the organization is a 'non-rational' system of values, beliefs and moral codes that motivate people. Central to the naturalsystem approach is the concept of homeostasis, or selfstabilisation, which spontaneously, or naturally, governs the necessary relationships among parts and activities and thereby keeps the system viable in the face of disturbances stemming from the environment (Thompson, 1967).

Barnard's combined approaches thus made valuable contributions to both the rational and natural schools of organization theory. Although this dichotomy in approach is contradictory, Barnard's work served as a platform for serious and sustained elaboration of his work by the SimonMarch-Cyert stream of study which produced a newer tradition evading the closed - versus - open system dilemma. This body of research viewed the organisation as a problem-facing and problem-solving phenomenon in an environment that is uncertain and does not fully disclose itself. Therefore, the organisation must make its decisions in bounded rationality and decision-making now involves satisficing rather than maximising (Thompson, 1967).

An integration of the Barnard-Simon-March-Cyert approaches gives the complex organisation as an open system, hence indeterminate and faced with uncertainty, but at the same time as subject to criteria of rationality and hence needing determinateness and certainty (Thompson, 1967).

\section{Practical perspectives}

According to McKenna (1991), the greatest challenges to the $21^{\text {st }}$ century manager include dealing with continually advancing technology, planning and controlling industrial growth and coping with the growing complexity of information management. Drucker (2002) further elaborated on management's new paradigms - strategy and planning in an uncertain and complex environment, transformational leadership, information frontiers, knowledge worker productivity and the role of individuals.

In this $21^{\text {st }}$ century turbulent environment, the key environmental, organisational and leadership themes illustrated in Barnard's work can be linked to the "compasssetting' tools described earlier - mission and vision statements, and strategic planning; as well as to the enactment of a corporate code of ethics and leadership. 


\section{Mission and vision statements}

Identification of the unique purpose of an organisation, its principal stakeholders and how to satisfy their needs in the environment within which the organisation operates, enables an organisation to develop a strategic plan to serve as a guideline for decision-making. By clarifying its guiding philosophy, an organisation anticipates that stakeholders will accept, trust and support it with the required resources (De Wit \& Meyer, 1998).

According to Bain (2003) a mission statement defines the organisation's business, its objectives and its approach to meeting those objectives; and a vision statement describes the desired future position of the organisation. Both statements are often combined to provide a statement of the organisation's purpose, goals and values and the terms are often used interchangeably. According to the Ashridgemodel (Chun, 2001; Campbell, 1992; Hooley, Cox \& Adams, 1992), a mission statement should consist of four components: purpose, values, strategy and behaviour standards.

Bartkus, Glassman and McAfee (2000) indicate that mission statements must reflect those values that are found in the organisational culture. False or hypocritical statements will evoke cynical reactions and lose all credibility. Since values are important determinants of employee behaviour in organisational settings, it thus becomes critical to match the value system of the individual with the value system of the organisation. However, where there is a lack of congruency, the strongest value system will dominate. 'With no unified corporate value system existing to serve as a referent, individuals would be particularly susceptible to group influence' (Liedtka, 1989). Thus an organisation with a strong organisational purpose and culture will dominate an employee-organisation relationship.

Barnard (1938:86) cited the requirement of a common purpose as an essential element of an organisation. He elaborated on this by stipulating that:

A purpose does not incite co-operative activity unless it is accepted by those whose efforts will constitute the organisation.

Thus while serving to inform individuals of the requirements of a co-operative organisation, Barnard's common purpose also serves as a measure of the satisfaction/sacrifice trade-off.

The purpose is considered good if the collection of individuals can use the purpose as a common focus to guide their co-operative efforts. However, the co-operative organisation will begin to disintegrate or reformulate its purpose, if individuals begin to differ in their beliefs in the ability of the purpose to offer an acceptable trade-off.

Central to this common purpose this is a willingness to cooperate, where the individual lays aside his/her internal, personal subjective motives, while embracing the external, impersonal, objective purpose of the organisation.
According to Barnard, there must be a willingness to serve or co-operate within the organisation. This is shown by giving up control over personal conduct. When a sufficient number of individuals have made such a choice, it gives rise to an attitude of cohesiveness within the organisation. Without this, the organisation will cease to exist, since there will not be a continual flow of personal contribution to a cooperative effort.

The importance of this aspect is apparent when the significant variability with regards willingness to contribute amongst people is considered. The majority of persons in a modern society always fall on the negative side. On the positive side, the majority will be no more than slightly positive and in a constant state of change. As a result, in an organisation, there are only a few that actually possess the willingness to co-operate, and the total sum of willingness to co-operate is an unstable, dynamic factor.

Willingness to co-operate is equal to the inducements to cooperate together with the sacrifices involved versus the net satisfactions available through the realizable alternatives. This is further complicated by the fact that to achieve a level of inducement such that the number of those willing to co-operate can be maximised, the organisation must not only counter the numerous alternatives and their ever-changing state, but must continually adapt to the variability in what constitutes an inducement.

Willingness to co-operate, except as a vague feeling or desire for association with others, cannot develop without an objective of co-operation (Barnard, 1938:86).

\section{Strategic planning}

Bain (2003) identified the popularity of strategic planning as a management tool, and described it as a comprehensive process used for determining what a business should do and how it can best achieve those goals. Its use enables the analyses of the full potential of a business and links the business's objectives to the actions and resources required to achieve them.

One of the main advantages of planning is its ability to improve the fit between the organisation and its external environment (Godiwalla, Meinhart \& Warde, 1981). The environment determines which organisations will survive and which ones will not, according to the population ecology perspective (Hannan \& Freeman, 1977; Ulrich, 1987). In today's turbulent environment, dynamic capabilities, flexibility, agility, speed and adaptability are critical and important sources of competitiveness (Barney, Wright \& Ketchen, 2001; Sushil, 2000).

In his approach to the relationship between the organisation and the environment, Barnard (1938:197) uses the basis of decision. In defining the environment and determining what factors are relevant and irrelevant, he notes that the use of organisational purpose is seen as essential.

This discrimination divides the world into two parts; the facts that are immaterial, irrelevant, mere background; and the part that contains the facts that apparently aid or 
prevent the accomplishment of purpose. As soon as that discrimination takes place, decision is in bud. It is in the state of selecting among alternatives.

Barnard (1938:196), however points out that this relationship between purpose and the environment has a bidirectional flow. Purpose, while giving meaning to the environment has no meaning without the environment.

Purpose itself has no meaning, however, except in an environment. It can only be defined in terms of an environment.......Thus back and forth purpose and environment react in successive steps through successive decisions in greater and greater detail.

Barnard sees the challenge in determining which environment to choose, when and how to engage with it, and how to navigate through it. The dynamic nature of the system, in turn continually transforms the purpose of the organisation and the environment in which the organisation operates. This in turn leads to a transformation of such magnitude such as to redefine the objectives of the organisation. With the redefinition of organisational objectives, comes a search for a new environment in which to exploit opportunistically the evolving competencies of the organisation in pursuit of its new redefined purpose. Thus a potentially endless cycle of dynamic interactions between the organisation and the environment is created.

Looking at the development of Barnard's common purpose and the environment, we find an echo by Quinn (1980), who writes of a new logical cohesion in goals that are set, and that the development of strategic goals for complex organisations is a delicate art, requiring a subtle balance of vision, entrepreneurship and politics. Quinn, describes the development of strategic goals through very complicated, largely political, consensus-building processes that are outside the structure of most formal management systems and frequently have no precise beginning or end. $\mathrm{He}$ further, points to avoiding the gimmickry of simplistic formal planning or MBO approaches for setting major goals (Quinn, 1980).

Quinn says that goals only come into being when they become intuitively understood and accepted guides for action. Effective goal processes, operate at three levels (Quinn 1980):

1. They define broadly what the organisation intends to be and what it should accomplish.

2. They ensure that each key person's role goals are designed to support these conceptual thrusts.

3. They obtain maximum identity between people's personal goals and their role goals.

It is interesting to note that Quinn recognises the dichotomy of purpose, described by Barnard - the individual motive and the organisational common purpose (Quinn, 1980).

Quinn's strategic goals emerge incrementally, in continual evolution, and the change processes are managed accordingly. Quinn suggests that the managing of a complex chain of interacting events and forces over a period of years to change strategic goals can be accomplished by the use of 'logical incrementalism' - constantly integrating the simultaneous incremental processes of strategy formulation and implementation (Quinn, 1980).

This matches Barnard's unstable, dynamic environment with the constantly changing criteria that constitute an inducement and subsequent acceptable satisfaction and the matching continual reformulation of the organisation's purpose and objectives.

Senge (1990) speaks of systems thinking - one of the pillars of his learning organisation. Systems thinking sees interrelationships rather than linear cause-effect chains; and sees processes of change rather than snapshots. In starting with a simple concept called feedback, which shows how actions can reinforce or counteract each other, it builds an organisation that can learn to recognise recurring patterns (Senge, 1990).

Senge departs from Barnard's viewpoint, when he postulates that the learning of an organisation serves to enable the organisation to recognise recurring patterns, while Barnard's cycle of dynamic interactions between the organisation and the environment also includes the unpredictable.

However, some commonality emerges between Senge and Barnard, with respect to Senge's theory of personal mastery - which is the discipline of continually clarifying and deepening vision, focusing energies, and seeing reality objectively (Senge, 1990). This concept of personal mastery, the cornerstone of the learning organisation, dove-tails neatly with Barnard's cycle of dynamic interactions between the organisation and the environment; where the environment and purpose are continually clarified and redefined.

A closer view of Barnard's dynamic interactions between the organisation and the environment leads to a focus on his 'strategic factors' which he relates to the term limiting factor - analogous to its application in scientific work, where it restricts or constrains a process.

The strategic factor always determines the action that is controlling......

The strategic factor, is then, the centre of the environment of decision (Barnard, 1938:205).

Having emphasised the crucial importance of strategic factors to decision-making and the environment, Barnard then goes on to specify the importance of using the right tools to measure these strategic factors, upon which the precision of decision depends.

Porter's framework of analytical techniques (Porter, 1980) to help firms analyse their industries lends precision to the decision upon which Barnard's interaction with the environment depends. The elements of Porter's general framework are analogous to Barnard's strategic / limiting factors. 
The meaning of effective decision - the control of the changeable strategic factors, that is, the exercise of control at the right time, right place, right amount, and right form so that purpose is properly redefined and accomplished (Porter, 1980:204).

Competitive advantage and indeed, opportunism can flourish when strategy is planned and strategic factors are identified, measured and controlled.

A key source of competitive advantage for the organisation, identified by Barnard, is the executive, whose unique characteristics and abilities are viewed by Barnard as innate traits of the individual. Porter echoes a similar refrain in looking at industry transition and the general manager, and the required managerial skills shift that occurs with the shift in the key requirements of the organisation that occurs during this transition (Porter, 1980). The implication being for the organisation, that an inadequate managerial skills shift can lead to a loss of competitive advantage - tying in with Barnard's claim to the executive as a source of competitive advantage.

\section{Code of Ethics and Leadership}

Petrick and Quinn (2001) argue that business leaders are not being held accountable for the costs incurred in neglecting integrity, thereby impairing the calculation of the costs thereof. They further suggest that this problem could be solved by expanding the scope of accountability of business leaders beyond maximising shareholder wealth to include societal problems. Worden (2003) builds on this concept and makes the case for integrity as a mediator in strategic leadership to enable a balance between organisational mission and society values.

The enactment of a code of ethics was a management tool identified by Bain (2003) as one that provided a top satisfaction ranking. A code of ethics is generally defined as a written, distinct formal document which consists of moral standards which help guide employee or corporate behaviour (Stevens, 1994; Hosmer, 1991; Townley, 1992). In the wake of the corporate collapses of Enron and Worldcom, the role of integrity and credibility on the reputational capital of an organisation has become critical (Worden, 2003). Therefore, it is not surprising that top executives are now promoting good conduct by setting a common standard for acceptable behaviour (Bain, 2003).

A significant positive correlation between a leader's integrity and organisational effectiveness was found by Parry and Procter-Thompson (2002). Credibility and trustworthiness, which are products of integrity, are important to effective leadership (Worden, 2003). Kouzes and Posner (1993) state that 'above all else, people want leaders who are credible; credibility is the foundation of leadership'. Central to leadership credibility is the inclusion of personal and organisational interest in the service of broader ideals. The leader's sense of personal purpose and commitment to the organisation's larger mission is integrated within the social reality of the business environment (Robert, 1991).
De Pree (1989) says that the first responsibility of a leader is to define reality. Therefore, a leader who can define the reality facing the organisation can construct an effective framework for its success (Caldwell, Bischoff \& Karri, 2002; De Pre, 1989). However, it is important to note that the interpretation of this reality is influenced by the manner in which a leader integrates and relates individual interests and group purpose (Rowsell \& Berry, 1993; Enderle, 1987).

Barnard carried the theme of the leader as a role model throughout his work.

Thus the endurance of organisation depends upon the quality of leadership; and that quality derives from the breadth of the morality upon which it rests (Barnard, 1938:282).

Barnard felt that leadership had to strike a balance among the individual personal interests of all those involved in the fortunes of the business. In these writings we also see Barnard's recognition of the modern style of transformational and visionary leadership as distinguished from the traditional transactional value style that was prevalent at the time.

Executive responsibility, then is that capacity of leaders by which, reflecting attitudes, ideals, hopes, derived largely from without themselves, they are compelled to bind the wills of men to the accomplishment of purposes beyond their immediate ends, beyond their times. Even when these purposes are lowly and the time is short, the transitory efforts of men become a part of that organisation of living forces that transcends man unaided by man; but when these purposes are high and the wills of many men of many generations are bound together they live boundlessly (Barnard, 1938:283).

Barnard (1938) offered what was then alternative ways to think about leading people in the workplace. He specifically defined formal organization in terms of the co-operation it elicited among members, paving the way for concepts such as empowerment and participation.

Purposeful co-operation is possible only within certain limits of a structural character, and it arises from forces derived from all who contribute to it. The work of cooperation is not a work of leadership, but of organisation as a whole (Barnard, 1938:259).

The executive in such a system is a facilitator of that cooperation. In his own words, Barnard (1938:216-7) observed that:

The executive functions serve to maintain a system of cooperative effort... The functions are not, as so frequently stated, to manage a group of persons. I do not think a correct understanding of executive work can be had if this narrower, convenient, but strictly speaking erroneous, conception obtains. It is not even quite correct to say that the executive functions are to manage the system of cooperative efforts. As a whole, it is managed by itself, not by the executive organization, which is a part of it. The functions with which we are concerned are like those of the 
nervous system, including the brain, in relation to the rest of the body. It exists to maintain the bodily system by directing those actions which are necessary more effectively to adjust to the environment, but it can hardly be said to manage the body, a large part of whose functions are independent of it and upon which it in turn depends.

As the above suggests, Barnard set the stage for moving beyond Taylor's control notion of management by offering a theoretical ground for participative leadership. $\mathrm{He}$ is consistent with today's paradigmatic shifts toward empowerment and non-linear thinking that cause us to reevaluate the role of guiding values versus work rules and routinization in the workplace.

The traditional view of authority at the time of Barnard's writing was that a superior's right to exact compliance from subordinates develops at the top and moves down through an organisation (Robbins \& DeCenzo, 1995). Barnard offered an alternate view - saying that authority comes from below. His acceptance view of authority argued that authority comes from the willingness of subordinates to accept it.

A person can and will accept a communication as authoritative only when four conditions exist:

a. He can and does understand the communication.

b. At the time of his decision he believes that it is not inconsistent with the purpose of the organisation.

c. At the time of his decision, he believes it to be compatible with his personal interest as a whole.

d. He is able mentally and physically to comply with it (Barnard, 1938:165).

Barnard believed that communication was the dominant function of management and the immediate origin of executive organisation. Executive communication was expected to be largely oral, face-to face and informal. Each executive was responsible for grasping a context and communicating it to others.

For Barnard, there was only two components of organised communication - the means and the system - the people were the means and the positions they held constituted the system. According to him, the centre of communication is the organisation service of a person at a place.

Barnard's ideas are matched by Zuboff (1988) in the posthierarchical organisational structure that she described where the abstract precincts of the data interface heighten the need for communication. Interpretive processes depend upon creating and sharing meaning through inquiry and dialogue. New sources of personal influence are associated with the ability to learn and to engender learning in others (Zuboff, 1988).
According to Barnard (1938:89), the dynamic nature of the organisation is emphasised by the element of communication.

The process by which these potentialities become dynamic is that of communication.

Barnard stated that the means through which an intricate set of ever-changing, always flowing pieces of information is exchanged between the organisation and the internal and external environment is communication.

He also included as communication exchanges both verbal and non-verbal pieces of information, with the goal being as complete an understanding as is possible for the true intent of the parties involved. Without communication as defined above, an organisation would not be able to communicate its purpose, develop the proper inducements, monitor and adjust to the constant change in alternatives, and carry out technical work functions.

Knowledge-based and professional intellect is portable. People with this profile regard the administrator as their enemy or as their servant and have the power to enforce their will by ignoring the administrators or by threatening to leave. They tend to be driven by problems challenging to themselves, and somewhat disdainful of all else (Quinn, 1992).

Inasmuch as the above is a phenomenon flourishing in the $21^{\text {st }}$ century, Barnard in 1938 addressed some of these concepts. He recognised that there is a duality of purpose of co-operation among people - the organisational purpose and the individual motive; strongly influenced by the degrees of free will and power of choice. Barnard states categorically that this free will and power of choice, while a fundamental part of man, is inherently limited by physical, biological and social forces.

....I believe in the power of the co-operation of men of free will to make men free to co-operate; that only as they choose to work together can they achieve the fullness of personal development; that only as each accepts a responsibility for choice can they enter into that communion of men from which arise the higher purposes of individual and of co-operative behaviour alike (Barnard, 1938:296).

Based on Barnard's postulates, managing of knowledge and professional intellect would entail ensuring that a persistence of co-operation existed viz. with respect to effectiveness and efficiency (as defined by Barnard, 1938: $60)$.

Effectiveness relates to the accomplishment of the cooperative purpose which is social and non-personal in nature. Efficiency relates to the satisfaction of individual motives and is personal in character. The test of effectiveness is the accomplishment of a common purpose or purposes; effectiveness can be measured. The test of efficiency is the eliciting of sufficient individual wills to cooperate. 
In these workers, 'knowledge is power' and efficiency requirements are high. Understanding that with these workers satisfying efficiency leads to satisfying effectivity is essential to unlocking the potential that resides in the intellectual capital base.

The management of professionals provides a prime situation for an 'inverted' organisation. Here true power does rest with the point person (Quinn, 1992). This ties in with Barnard's acceptance view of authority which argued that authority comes from the willingness of subordinates to accept it.

Since determination of authority lies with the subordinate individual, Barnard, further postulated that co-operation could be secured because a zone of indifference existed for each individual within which orders are accepted without conscious questioning of their authority. This was linked to the argument by Barnard that the foundation of good leadership was morality and that a key element of this morality was responsibility.

.... the quality which gives dependability and determination to human conduct, and foresight and ideality of purpose (Barnard, 1938:260).

\section{Conclusions}

Energy can neither be created nor destroyed. It can only be converted from one form into another - The First Law of Thermodynamics, a scientific theory that drives practice. The amount of energy (example: electrical or mechanical work) that a machine can produce is equivalent to the amount of energy supplied to it (Eagleson, 1994). However, rigorous scientific theory does not appear to drive management practice. Instead, practising managers generally have to work their way through the trial and error applications of the many theories.

The focus, the questions, the methods and the analyses of these many theories are diverse. They cannot be portrayed as an orderly succession of ideas or a unified body of knowledge in which each improvement builds on and advances the one before it. In fact, their underlying contradiction is the pull between task and people, between the scientific and the humanistic approach.

Having traced a trajectory of management thought by examining the place of the seminal work of Chester I Barnard of the classical management school, in the light of contemporary trends and problems and debated the currency of fundamental management principles; it can be seen that many of the issues that confound management practitioners today have been touched upon by classical writers - albeit with different words.

It is an interesting phenomenon to see that, that which is touted as fundamentally 'new management practice' is essentially the adaptation of existing 'old management truths'. In the $21^{\text {st }}$ century, work life has changed as indicated by the rise in knowledge-intensive-firms, and the emergence of worker elites. However, how to view them and the potentialities they present have their pedigree and genesis in earlier literature.

Analysing the original work of early management pioneers Taylor, Barnard, and others - can provide a different perspective from what is sometimes attributed to them by subsequent writers. Reading the original, authentic work, and not another's interpretation of it, provides refreshing viewpoints, as interpretations can often lose the essence and intention of the writer and reflect instead the opinions and interpretations of the analyst.

The works reviewed here are mainly American, and of the developed world. Given the state of globalisation, the juxtaposition of first and third world economies in many developing countries as well as the diverse cultural, social and physical variations that exist, this paper therefore suggests the implementation of contextual variations - that industry-level, country-level and firm-specific factors be the determinants of the translation of management theory into action.

Contextual variation of fundamental concepts: the solution to contemporary management problems - a sine qua non!

\section{References}

Abrahamson, E. 1996. ' Management fashion'. The Academy of Management Review, 21 (1): 254.

Bain. 2003. 'Management tools.' [online] URL http://www.bain.com. Accessed 3 March 2004.

Barnard, C.I. 1938. The functions of the executive. Cambridge, MA: Harvard University.

Barney, J., Wright, M. \& Ketchen, D.J. 2001. 'The resourcebased view of the firm: Ten years after 1991', Journal of Management. 27: 625-641.

Bartkus, B., Glassman, M. \& McAfee, B. 2000. 'Mission statements: Are they smoke and mirrors?' Business Horizons, Nov/Dec: 23-28.

Benders, J. \& van Veen, K. 2001. 'What's in a fashion? : Interpretative viability and management fashions', Organisation, 8(1): 33-53.

Caldwell, C., Bischoff, S.J. \& Karri, R. 2002. 'The four umpires: A paradigm for ethical leadership', Journal of Business Ethics. 36: 153-163.

Campbell, A. 1992. 'The power of mission: Aligning strategy and culture', Planning Review (Special Issue), Sept/Oct: 20(5) : 11 .

Chun, R. 2001. 'E-reputation: The role of mission and vision statements in positioning strategy', Journal of Brand Management. 8: 315-334.

Cyert, R.M. 1963. A behavioural theory of the firm. EngelwoodCliffs NJ: Prentice-Hall. 
De Wit, B. \& Meyer, R. 1998. Strategy, process, content, context. An international perspective. $2^{\text {nd }}$ Edition. London:Thompson Business Press.

DePree, M. 1989. Leadership is an art. New York: Doubleday.

Drucker, P. 2002. Management challenges for the $21^{\text {st }}$ century. Oxford: Reed/Butterworth-Heinemann.

Eagleson, M. 1994. Concise encyclopedia of chemistry. Berlin: W de Gruyter \& Co.

Enderle, G. 1987. 'Some perspectives of managerial ethical leadership', Journal of Business Ethics, 6(8): 657-663.

Fink, D. 2003. 'A lifecycle approach to management fashion: An investigation of management concepts in the context of competitive strategy', Schmalenbach Business Review, 55: 46-59.

Godiwalla, Y.M., Meinhart, W.A. \& Warde, W.A. 1981. 'General management and corporate strategy, Managerial Planning, 30: 17-29.

Hannan, M. \& Freeman, J. 1977. 'The population ecology of organizations', American Journal of Sociology, 82: 929-964.

Hooley, G.J., Cox, A.J. \& Adams, A. 1992. 'Our five year mission - To boldly go where no man has gone before', Journal of Marketing Management, 8(1) : 35-48

Hosmer, L.T. 1991. The ethics of management. $2^{\text {nd }}$ Edition. Boston, MA.: Irwin Inc.

Kiesser, A. 1997. 'Rhetoric and myth in management fashion', Organisation, 4(1): 49-76.

Kouzes, J.M. \& Posner, B.Z. 1993. Credibility: How leaders gain and lose it, why people demand it. San Francisco: Jossey-Bass.

Liedtka, J.M. 1989. 'Value congruence: The interplay of individual and organisational value systems', Journal of Business Ethics, 8(10): 805-815.

March, J.G. \& Simon, H.A. 1958. Organisations. New York:John Wiley and Sons.

McKenna, J.F. 1991. 'Management in the $21^{\text {st }}$ century: A modest proposal', SAM Advanced Management Journal. 56(4):4.

Micklethwait, J. \& Wooldridge, A. 1996. The witch doctors: Making sense of the management gurus. New York: Times Books.

Morgan, G. 1986. Images of an organisation. London: Sage Publications.

Parry, K.W. \& Proctor-Thompson, S.B. 2002. 'Perceived integrity of transformational leaders in organisational settings', Journal of Business Ethics, 35(2): 75-96.
Pascale, R.T. 1990. Managing on the edge. New York: Simon \& Shuster.

Petrick, J.A. \& Quinn, J.F. 2001. 'The challenges of leadership accountability for integrity capacity as a strategic asset', Journal of Business Ethics, 24(4): 334-343.

Porter, M. 1980. Competitive strategy. New York: Free Press.

Quinn, J.B. 1980. Strategies for change: Logical incrementalism. Homewood: Irwin.

Quinn, J.B. 1992. Intelligent enterprises. New York: Free Press.

Rigby, D. 2003. 'Management tools survey 2003: Usage up as companies strive to make headway in tough times', Strategy and Leadership, 31(5):4.

Robbins, S.P. \& DeCenzo, D.A. 1995. Fundamentals of management. New Jersey: Simon \& Shuster.

Robert, M. 1991. The essence of leadership innovation and decisiveness. New York: Quorum Books.

Rowsell, K. \& Berry, T. 1993. 'Leadership, vision, values and systematic wisdom', Leadership and Organisational Development Journal, 14(7): 18-22.

Senge, P. 1990. The fifth discipline. New York: Doubleday.

Stevens, B. 1994. 'An analysis of corporate ethical code studies: Where do we go from here?' Journal of Business Ethics, 13: 63-69.

Sushil. 2000. Flexibility in management. New Delhi: Vikas Publishing House.

Taylor, F.W. 1947. Scientific management. New York:Harper And Row.

Thompson, J.D. 1967. Organisations in action. New York: The Free Press.

Townley, P. 1992. 'Business ethics ... An oxymoron?' Canadian Business Review. Spring: 35-37

Ulrich, D. 1987. 'The population perspective: Review, critique and relevance', Human Relations, 40: 137-152

Worden, S. 2003. 'The role of integrity as a mediator in strategic leadership: A recipe for reputational capital', Journal of Business Ethics, 46 (1): 31.

Zuboff, S. 1988. In the age of the smart machine: The future of work and power. New York: Basic Books. 